\title{
PRESSURE MICROINJECTION OF NERVE GROWTH FACTOR AND ANTI-NERVE GROWTH FACTOR INTO THE NUCLEUS AND CYTOPLASM: LACK OF EFFECTS ON NEURITE OUTGROWTH FROM PHEOCHROMOCYTOMA CELLS ${ }^{1}$
}

\author{
P. JOHN SEELEY, ${ }^{2}$ CHARLES H. KEITH, MICHAEL L. SHELANSKI, AND LLOYD A. GREENE \\ Department of Pharmacology, New York University School of Medicine, New York, New York 10016
}

Received December 3, 1982; Revised February 25, 1983; Accepted March 2, 1983

\begin{abstract}
Exogenous protcins have becn introduced into naive and nerve growth factor (NGF)-primed pheochromocytoma cells by pressure microinjection. Microinjection of cells did not affect NGFinduced neurite outgrowth by these cells over periods of up to 3 days. Injected NGF failed to elicit neurite outgrowth or regeneration in the absence of extracellular NGF and failed to enhance it in its presence. Injected anti-NGF IgG failed to inhibit neurite outgrowth or regeneration induced by extracellular NGF. Similar results were obtained for both nuclear and cytoplasmic injections.
\end{abstract}

It is the conventional view that peptide hormones bind to specific receptors on the surface of a target cell and subsequently are internalized. The internalization results in degradation of the hormone but may also serve to transport the peptide to an intracellular locus of action (e.g., the nucleus). It is not known whether responses of the target cell may be provoked solely from the cell surface, by direct or indirect action of the hormone intracellularly, or by simultaneous action from both locations. In the case of nerve growth factor (NGF), a chemically defined agent which promotes the survival and development of peripheral sensory and sympathetic neurons, there is evidence for both specific cell surface receptors for NGF (Greene and Shooter, 1980; Yankner and Shooter, 1982) and NGF internalization (Hendry et al., 1974; Norr and Varon, 1975; Andres et al., 1977), but little information on the role of internalized hormone. Possibilities for direct involvement of NGF in transcriptional and non-transcriptional events have recently been investigated by several groups using $\left[{ }^{125} \mathrm{I}\right] \mathrm{NGF}$ in subfractionation (Yankner and Shooter, 1979) or autoradiographic studies (Schwab and Thoenen, 1977; Carbonetto and Stach, 1982; Claude et al., 1982; Hogue-Angeletti et al., 1982; Rohrer et al., 1982; Bernd and Greene, 1983) or examining the interaction of NGF with cytoskeletal proteins (Levi et al., 1975; Calissano et al., 1978;

\footnotetext{
${ }^{1}$ This work was supported by National Institutes of Health Grants NS16036 and NS15076. P. J. S. was a North Atlantic Treaty Organization Fellow over part of the period covered by this work. L. A. G. holds an Irma T. Hirschl Career Development Award.

${ }^{2}$ To whom correspondence should be addressed, at Department of Pharmacology, N.Y.U. School of Medicine, 550 First Avenue, New York, NY 10016.
}

Nasi et al., 1982). There is some evidence for association of exogenous NGF with nuclear structures (Andres et al., 1977), particularly the nuclear membrane (Yankner and Shooter, 1979; Bernd and Greene, 1983); others do not observe significant nuclear labeling (Claude et al., 1982; Hogue-Angeletti el al., 1982; Rohrer et al., 1982) and they ascribe previous observations to system artifact (Rohrer et al., 1982). Also, NGF has been shown to bind to, and to alter the polymerization of, tubulin (Levi et al., 1975) and actin (Calissano et al., 1978; Nasi et al., 1982). While these experimental approaches are valuable, it is not possible to assess the functional significance of a particular level of cytoplasmic or nuclear NGF using these techniques.

Our approach to determining the role of intracellular NGF has been to introduce the protein or its antibody directly into a responsive cell by means of glass micropipettes which penetrate the plasmalemma and through which materials may be injected by pressure. We describe in this paper the effects of microinjected NGF and of microinjected antibodies to NGF on the outgrowth of neurites from the clonal pheochromocytoma line PC12 (Greene and Tischler, 1976, 1982). With this target cell, both transcription-dependent initiation of outgrowth and transcription-independent regeneration can be studied, since cell survival is independent of the presence of NGF. Our experiments cover nuclear and cytoplasmic injection of material and both rapid (1-day) and longer term (3day) neurite responses from the PC12 ccll.

\section{Materials and Methods}

Cell culture. The rat pheochromocytoma clone PC12 was grown in medium made up of $85 \%$ Roswell Park 
Memorial Institute Medium (RPMI) 1640 (Grand Island Biological Co.), $10 \%$ heat-inactivated horse serum (K.C. Biological), and 5\% fetal calf serum (K.C. Biological) (v/ v) at $36^{\circ} \mathrm{C}$ in a water-saturated, $7.5 \%$ carbon dioxide atmosphere. Cells were plated onto an adhesive substratum consisting of an air-dried mixture of collagen and polylysine. The amount of rat-tail collagen used (Bornstein, 1958) was determined empirically as the minimum giving satisfactory NGF-induced neurite outgrowth from PC12 when used alone, and this was supplemented with $10 \mu \mathrm{g}$ of polylysine hydrobromide/dish $(60-\mathrm{mm}$ diameter). A mixed solution of collagen and polylysine was airdried onto the dishes over a period of hours. Dishes treated in this way were equilibrated with culture medium for $2 \mathrm{hr}$ prior to plating of cells. The cell density was $5.2 \times 10^{4} \mathrm{~cm}^{-2}$.

For regeneration experiments, PC12 cells were "primed" by maintenance in RPMI 1640 containing $1 \%$ horse serum and $50 \mathrm{ng} \mathrm{ml}^{-1}$ of NGF for at least 7 days prior to their use. Neurites were broken off as the cells were removed from the dish by expulsion of medium from a Pasteur pipette and also in the subsequent triturations to break up clumps of cells. In order to remove adherent NGF, samples were washed three times in 10 $\mathrm{ml}$ of NGF-free medium before replating onto collagen + polylysine-treated dishes. Since the half-time for loss of the capacity for rapid, NGF-induced neurite outgrowth is about $16 \mathrm{hr}$ (Burstein and Greene, 1978), microinjections were carried out no more than $4 \mathrm{hr}$ after replating.

Sources of materials and chemicals. NGF $(2.5 \mathrm{~S})$ was prepared in our laboratory by the method of Mobley et al. (1976). Fluorescein isolhiocyanate, bovine serum albumin, and ovalbumin were from Sigma Chemical Co., St. Louis, MO, and tetramethylrhodamine isothiocyanate was from Research Organics, Inc., Cleveland, $\mathrm{OH}$. Formaldehyde solution $(37 \% \mathrm{w} / \mathrm{v})$ was obtained from Fisher Scientific Co., Pittsburgh, PA.

Preparation of anti-NGF and of an anti-NGF IgG fraction. Anti-NGF was prepared using rabbits as described previously (Zanini et al., 1968) and was employed at a dilution (1:200) sufficient to neutralize in excess of $50 \mathrm{ng} \mathrm{ml}^{-1}$ of NGF.

An anti-NGF IgG fraction was prepared from this antiserum by ammonium sulfate fractionation and DEcellulose chromatography. Solid ammonium sulfate (2.3 $\mathrm{gm}$ ) was slowly added to $10 \mathrm{ml}$ of antiserum. The mixture was allowed to stand for $1 \mathrm{hr}$ at room temperature and then was centrifuged at $8000 \mathrm{rpm}$ for $20 \mathrm{~min}$. The pellet was taken up in $5 \mathrm{ml}$ of $5 \mathrm{~mm}$ sodium phosphate, $\mathrm{pH} 6.5$, and then dialysed against two 1-liter aliquots of the same buffer. Pre-swollen DE-52 (3 gm), which had been preequilibrated with $5 \mathrm{~mm}$ sodium phosphate, $\mathrm{pH} 6.5$, was added to the dialysed serum fraction, and the mixture was agitated gently for $60 \mathrm{~min}$ at room temperature. Centrifugation gave a supernatant IgG fraction which was dialysed against water, lyophilized, and redissolved in a small volume of buffer $M$ (see below). This solution was assayed for its ability to inhibit PC12 neurite regeneration induced by $50 \mathrm{ng} \mathrm{ml}^{-1}$ of NGF and had a titer of 1:3000.

Preparation of rhodamine/ovalbumin (RO). RO was prepared by adding $0.1 \mathrm{vol}$ of rhodamine isothiocyanate (10 $\mathrm{mg} \mathrm{ml}^{-1}$ in dimethyl sulfoxide) to ovalbumin (10 $\mathrm{mg}$ $\mathrm{ml}^{-1}$ ) dissolved in $100 \mathrm{~mm}$ sodium borate, $\mathrm{pH}$ 8.5. The mixture was incubated at $37^{\circ} \mathrm{C}$ for $1 \mathrm{hr}$ and then dialysed extensively against half-strength phosphate-buffered saline (PBS). The solution was sterile-filtered and stored frozen.

Preparation of fluorescein/hovine serum albumin $(F B)$. FB was prepared by adding $100 \mathrm{ml}$ of $0.5 \mathrm{~mm}$ fluorescein isothiocyanate in $50 \mathrm{~mm}$ sodium phosphate +75 mM sodium chloride, $\mathrm{pH} 9.5$, to $10 \mathrm{ml}$ of $30 \mathrm{mg} \mathrm{ml}^{-1}$ bovine serum albumin. The protein was dissolved in the same buffer and was contained in a dialysis bag. Reaction was allowed to proceed for $16 \mathrm{hr}$ at $4^{\circ} \mathrm{C}$ and was then terminated by extensive dialysis at room temperature against half-strength PBS until color was no longer detectable in the dialysate. The FB solution was sterilefiltered before storage.

Pressure microinjections. Pipettes for microinjections were drawn from 1-mm outside diameter glass tubes (TW100F, W-P Instruments, Inc., New Haven, CT) using an M1 micropipette puller (Industrial Science Associates, New York, NY). Tip diameters were estimated as $0.5 \mu \mathrm{m}$. Micropipettes were backfilled with injection solutions and fitted into a tubular pipette holder (Leitz) which was connected by plastic tubing to a glass $50-\mathrm{ml}$ gas syringe. The pipelle holder was attached to a Leitz micromanipulator used for steering the micropipette. Injections were visualized with a Leitz Diavert inverted microscope.

The injection solutions were: $F B$, fluorescein/bovine serum albumin derivative, $10 \mathrm{mg} \mathrm{ml}^{-1}$ in buffer $\mathrm{M}(50$ mM 2-( $N$-morpholino)ethane sulfonate $+0.5 \mathrm{~mm}$ magnesium chloride, $\mathrm{pH} 6.9$ ); $R O$, rhodamine/ovalbumin derivative diluted to $3 \mathrm{mg} \mathrm{ml}^{-1}$ with buffer $\mathrm{M}( \pm 0.5 \mathrm{vol}$ of 50 mm sodium acetate, $\mathrm{pH} 5.0) ; R O+N G F, 1 \mathrm{vol}$ of RO to $1 \mathrm{vol}$ of NGF $\left(250 \mu \mathrm{g} \mathrm{ml}^{-1}\right.$ in $50 \mathrm{~mm}$ sodium acetate, pH 5.0); RO + AbNGF (antibodies to NGF), 1 vol of RO to 1 vol of anti-NGF IgG (titer, 1:3000) in buffer M. To remove particulate material which would otherwise have blocked the micropipettes, fluorescent markers were passed through $0.22-\mu \mathrm{m}$ Millipore filters (SLGS0250S) and added to NGF or its antibodies, and then the mixture was centrifuged at $13,000 \times g$ for $10 \mathrm{~min}$ immediately prior to use.

Plates were marked on their undersides in order to delimit areas in which microinjection was to take place. Sterile HEPES buffer (5 to $10 \% ; 250 \mathrm{~mm}$, pH 7.4; sodium salt) was added to the medium in each plate to stabilize extracellular $\mathrm{pH}$. Normally, 50 cells were injected per dish. Subsequently the cclls were washed three times with $3 \mathrm{ml}$ of complete medium to remove HEPES buffer and any material spilled in the course of microinjection, and then either NGF or anti-NGF serum was added. After the appropriate period of incubation under the standard culture conditions, plates were gently washed twice with $3 \mathrm{ml}$ of PBS, and the injected cells, identified from fluorescence of co-injected $\mathrm{RO}$ or $\mathrm{FB}$, were scored immediately for process growth using a Leitz Ortholux fluorescence microscope fitted with a Zeiss Neofluar $x$ 25 water-immersion phase objective. Cells were then fixed for about $2 \mathrm{hr}$ in PBS containing $3.7 \%(\mathrm{w} / \mathrm{v})$ formaldehyde, gently washed in PBS, and rescored using an inverted microscope for process outgrowth from noninjected cells lying outside the delimited area. The effects of injection were thus determined by direct comparison 
with non-injected cells in the same plate. Sister cultures of non-injected cells (signified by open squares in Figs. 2 and 3), given the complementary treatment with either NGF or anti-NGF serum, were used for assessment of NGF-dependent or spontaneous process growth, respectively. If the medium for cultures of injected cells contained NGF, sister cultures were kept in NGF-free medium; if the medium for cultures of injected cells contained antiserum to NGF (AsNGF), sister cultures were kept in NGF-containing medium. Hence, for experiments on naive cells, seven cultures were set up. On day 0 , three cultures were injected and a fourth culture was scored. Subsequently, one injected culture and one sister culture were scored on each of days 1,2 , and 3. Arrangement of individual experiments is described in detail in the figure legends.

Quantification of injection volume. It was necessary to measure the injection volume in order to determine the moles of protein injected. To do so, fluorescence intensity from cells microinjected with $\mathrm{RO}$ was compared quantitatively with that from a small, known volume of a standard solution of the injected RO. Fluorescence intensity was measured from microinjected cells using a Leitz Orthoplan microscope equipped with an MPV photometer. Background fluorescence from non-injected cells was also determined. The standard injection solution used for comparison was diluted into PBS and contained in a hemacytometer. Fluorescence measurements were made on the standard with the same microscope configuration used for cells. Since the size of the measuring aperture was known (90 $\mu \mathrm{m}$ diameter) and the thickness of the RO solution was set by the hemacytometer $(100 \mu \mathrm{m})$, the volume of the standard solution contributing fluorescence could be determined. (Independent checks with "sandwiches" of RO solution in microcuvettes constructed from coverglasses of various thicknesses confirmed that the epifluorescence was collected with $100 \%$ efficiency to thicknesses in excess of 100 $\mu \mathrm{m}$. The fluorescence intensity was also linear with RO concentration.) Care was taken to avoid photobleaching of RO in the course of measurement. The injection volume derived in this way was $200 \pm 40 \mathrm{fl}$ ( \pm SEM, 20 cells). For cytoplasmic injections, therefore, the amounts injected were: $7 \times 10^{-19} \mathrm{~mol} / \mathrm{cell}^{-1} \mathrm{NGF}$; anti-NGF IgG equivalent to at least $6 \times 10^{-19} \mathrm{~mol} / \mathrm{cell}^{-1} \mathrm{NGF}$. These values are to be compared with values of $10^{-20} \mathrm{~mol} / \mathrm{cell}^{-1}$ for the content of $\left.{ }^{125} \mathrm{I}\right] \mathrm{NGF}$ of PC12 cells maintained in $5 \mathrm{ng} \mathrm{ml}^{-1}$ of $\left.{ }^{125} \mathrm{I}\right] \mathrm{NGF}$ for 1 day (Yankner and Shooter, 1979 ). Since the volume of a naive PC12 cell was estimated as $600 \pm 13 \mathrm{fl}( \pm \mathrm{SEM})$ from the diameters of floating cells (assuming sphericity), our estimate of injection volume as a fraction of cell volume $(\sim 30 \%)$ is significantly greater than those of others $(\sim 10 \%)$ (e.g., Beckerle and Porter, 1982), though the viability of injected cells in our experiments was consistently at least $79 \%$. The latter determinations, however, used different methods on different cell types. Even if the $10 \%$ values pertained in the present case, the amount of NGF (or antibody equivalent) injected is considerably in excess of that accumulating in the cell by conventional endocytotic means under conditions capable of eliciting process growth.

\section{Results}

Cytoplasmic injection of marker. A highly fluorescent rhodamine isothiocyanate derivative of ovalbumin (rhodamine ovalbumin, $\mathrm{RO}$ ) was used as a marker for injected cells in all experiments reported here. This material did not appear to alter cells into which it was injected, in contrast to fluorescein isothiocyanate derivatives which were frequently cytotoxic, either of themselves, or due to increased absorption of room light. Non-injected cells were autofluorescent under rhodamine excitation, but their fluorescence level was considerably less than that for injected cells. Injected cells were not scored unless their fluorescence intensity was at least 5 times this background. (This reference level was set using the photometer.) Fluorescence and phase contrast micrographs of injected cells are shown in Figure 1. The culture had been treated with NGF for 1 day postinjection and prior to photography, and this resulted in growth of processes by injected cells in a manner identical to that for noninjected counterparts. The cell bodies appeared uniformly fluorescent and the processes could also be traced by their fluorescence, a situation which assisted in the scoring of injected cells.

Process outgrowth induced by externally applied NGF in naive $\mathrm{PC} 12$ cells injected with $\mathrm{RO}$ alone was quantified in an experiment presented in Figure $2 A$. On day 0,50 cells in each of three culture dishes were injected with $\mathrm{RO}$ solution. The injected cells were located in markedoff areas of the dishes. Subsequently, these cultures were washed with medium and incubated with $50 \mathrm{ng} \mathrm{ml}^{-1}$ of NGF. At daily intervals a dish containing injected cells was scored for the percentage of fluorescent cells having processes of $10 \mu \mathrm{m}$ or greater length. (Scored cells were required to have fluorescence of at least 5 times background and to be entirely healthy in appearance.) The dish was then fixed by the addition of $4 \%$ glutaraldehyde to the medium, and non-injected cells, lying outside the delimited area, were scored for $10-\mu \mathrm{m}$ processes. Culture dishes that had not received NGF treatment were fixed and scored similarly. (RO-containing cells were sensitized to fluorescence excitation by the high internal levels of fluorophore, and scoring of these cells was thus cytotoxic. Therefore, they could not be assessed on subsequent days for the development of processes.) The effects of injected $\mathrm{RO}$ on process outgrowth from naive $\mathrm{PC} 12$ cells are illustrated in Figure 2A. NGF induced significant process outgrowth, and after 3 days, about $70 \%$ of cells had processes of $10 \mu \mathrm{m}$ or greater. Responses for ROinjected and non-injected control cells were essentially identical, and RO itself did not induce process outgrowth. In addition, the great majority of injected cells showed no evidence of necrosis. For this experiment $78 \%$ of cells injected were scored. Of all the cells injected, $85 \%$ were located (and had fluorescence 5 times background); a few cells, in this case $7 \%$ of the total, were indeterminate for process growth because they were partially obscured by adjacent cells. For all of the experiments reported here, $79 \%$ of the injected cells were identified.

Cyloplasmic injeclion of NGF into naive cells. Can NGF which has been injected into the cytoplasm induce process outgrowth in the absence of extracellular NGF? 

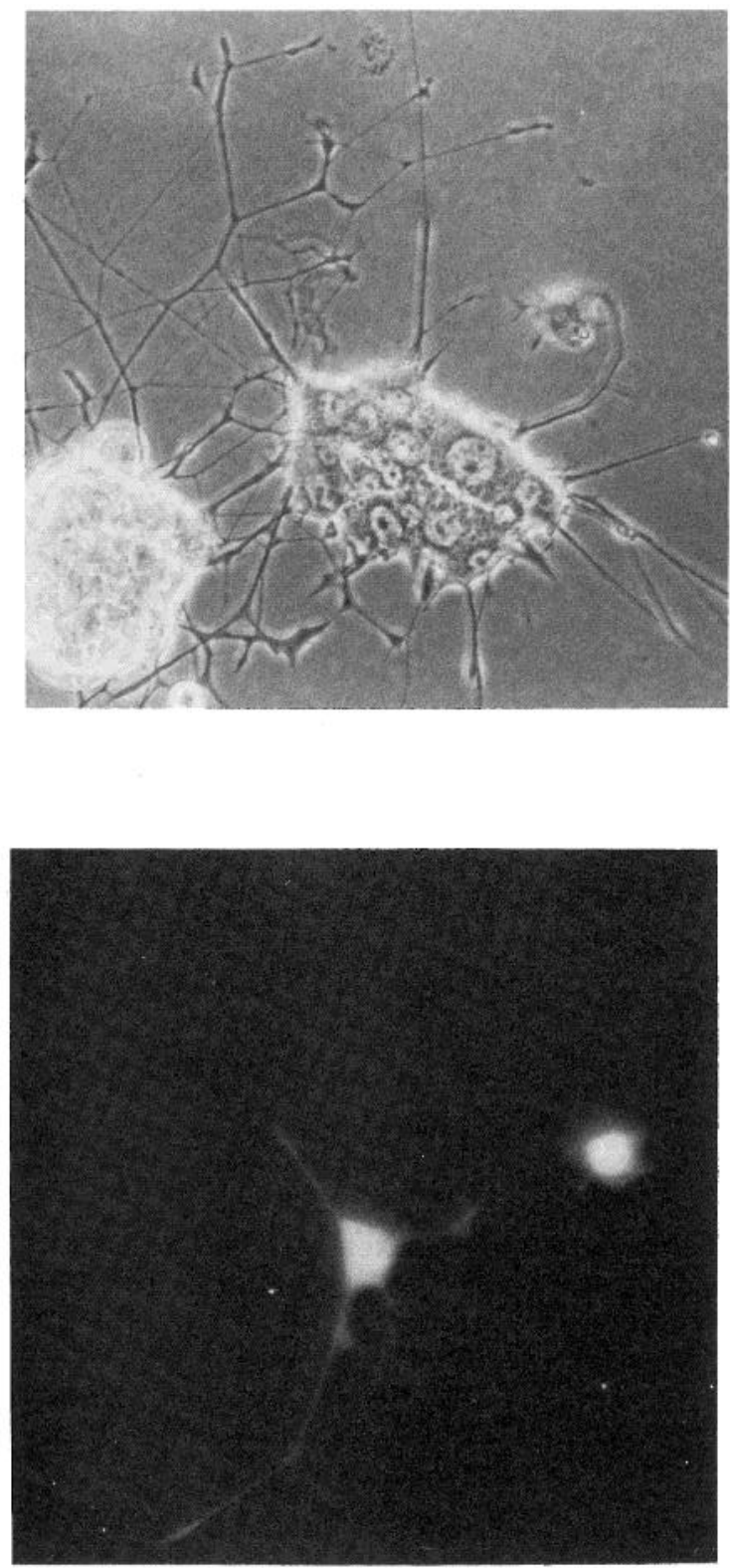

Figure 1. Phase contrast and fluorescence micrographs of a PC12 culture. Cells were "primed" by 10-day exposure to $50 \mathrm{ng}$ $\mathrm{ml}^{-1} \mathrm{NGF}$ and replated, and then a number of cells were injected with RO. The two photographs are a phase contrast and fluorescence pair of the same field of cells and were taken after $24 \mathrm{hr}$ exposure to extracellular NGF (50 $\left.\mathrm{ng} \mathrm{ml}^{-1}\right)$.

In this case NGF was co-injected with RO as marker and with antiserum to NGF added to the culture medium. Use of this antiserum prevented stimulation of cell surface NGF receptors by factor spilled into the medium during injection or released by injected cells. Similar results were obtained in the absence of antiserum when cultures were washed after injection. The protocol was identical to that used for the control RO injections. Results are plotted in Figure $2 B$. NGF injected into the cytoplasm did not induce process outgrowth compared with non-injected cells in the same culture dishes, despite the obvious responsiveness of the (non-injected) sister cultures to extracellularly applied NGF. The injected
PER CENT CELLS WITH PROCESSES

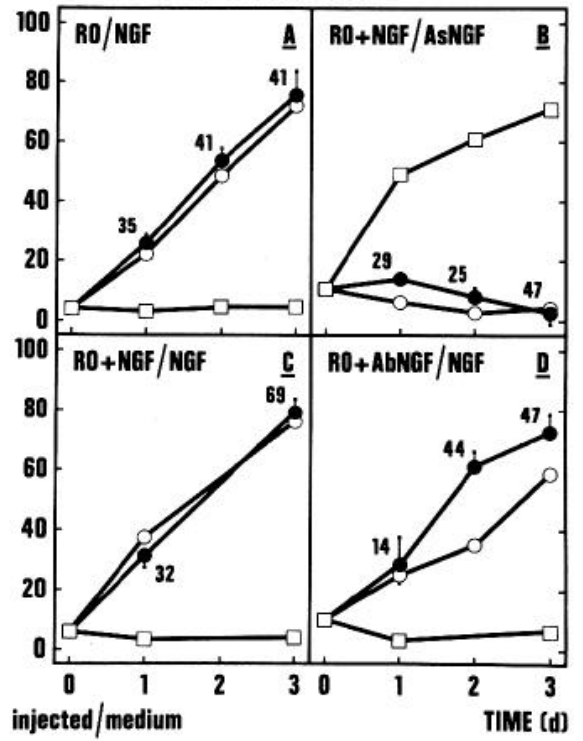

Figure 2. Neurite outgrowth from naive cells: cytoplasmic injections. Naive cells were treated with NGF as described under "Materials and Methods." A cell was scored as positive for process growth if it had at least one process of $10 \mu \mathrm{m}$ or more in length. 9 , microinjected cells; $\bigcirc$, control, non-injected cells present in the same plate as microinjected cells; $\square$, cells from non-injected sister cultures given the converse external NGF treatment to injected cells. That is, for $A$, the injected and non-injected cells were supplied with extracellular NGF, whereas sister cultures were maintained in NGF-free medium; in $B$, injected and non-injected cells received extracellular AsNGF, whereas sister cultures received extracellular NGF; in $C$, injected and non-injected cells received extracellular NGF, whereas sister cultures were in NGF-free medium; in $D$, injected and non-injected cells received extracellular NGF, whereas sister cultures were in NGF-free medium. Compositions of the injection solutions and of the media, indicated in $A$ to $D$ as injected solution/medium, are given under "Materials and Methods." The number adjacent to each solid circle is the number of injected cells scored for that datum point. The error bars for injected cells were estimated by scoring six equivalent groups of non-injected cells. The number in each of these groups was the number of injected cells scored. The error bars for injected cells are therefore valid estimates if it is assumed that outgrowths from injected and non-injected cells are the same. The error bars plotted for the injected cell points are standard deviations. In other cases the data points are each based on counts of 300 cells and the error bars are standard errors of the means; most of these error bars lie within the limits of the data symbols.

cells were similar in other aspects of morphology to untreated PC12 cells. They did not, for example, show any of the NGF-dependent flattening (P. J. Seeley, L. Blum, and L. A. Greene, unpublished observations) or hypertrophic (Greene and Tischler, 1976; Gunning et al., 1981) responses.

If cytoplasmic NGF is unable to provoke process outgrowth, can it enhance or otherwise affect outgrowth induced by extracellular NGF? For this experiment NGF was co-injected with RO marker and simultaneously added to the culture medium at $50 \mathrm{ng} \mathrm{ml}^{-1}$. Process outgrowth (Fig. $2 C$ ) was not any more rapid or extensive 
for injected cells than for controls receiving NGF solely from the extracellular space. Thus, in these experiments, NGF injected into the cytoplasm did not show any activity in a neurite generation assay extending over several days.

Cytoplasmic injection of anti-NGF into naive cells. The converse of the above experiment is to test for inhibition of NGF-induced process outgrowth by injected anti-NGF antibody. For this purpose an IgG fraction active against $\mathrm{NGF}$ was separated from antiserum and co-injected with RO. Injected anti-NGF IgG did not inhibit process outgrowth induced by extracellular NGF (Fig. 2D). The antibody stimulation of outgrowth observed here (Fig. $2 D$ ) has not been observed consistently; in other versions of this experiment, process growth with injected antibody was somewhat less than in controls.

Nuclear injections of naive cells. Since evidence has been cited for location of NGF at the nucleus (Andres et al., 1977; Yankner and Shooter, 1979; Bernd and Greene, 1983) and since permeability of the nuclear membrane is potentially limiting, at least for anti-NGF IgG (Kulka and Loyter, 1979), some intranuclear microinjections were carried out. RO appears permeant to the nuclear membrane; therefore, the efficacy of nuclear injections was assessed from microinjection of fluorescein conjugates of bovine serum albumin (FB). One day after nuclear injection of FB, there was bright fluorescence over the nucleus and much fainter fluorescence over the cytoplasm. This form of injection is therefore more precisely described as "predominantly nuclear." Since, as noted above, some samples of FB were cytotoxic over longer periods of incubation, RO was used as the marker for nuclear injection experiments. Recovery of cells from RO nuclear injections was $46 \%$, which was less than the recovery for cytoplasmic injections. It is not known whether this was due to fluorescence intensity effects or cell death from injection. Results of experiments in which naive PC12 cells were injected with either RO + NGF or $\mathrm{RO}+$ anti-NGF IgG are shown in Figure 3. NGF injected

PER CENT CELLS WITH PROCESSES

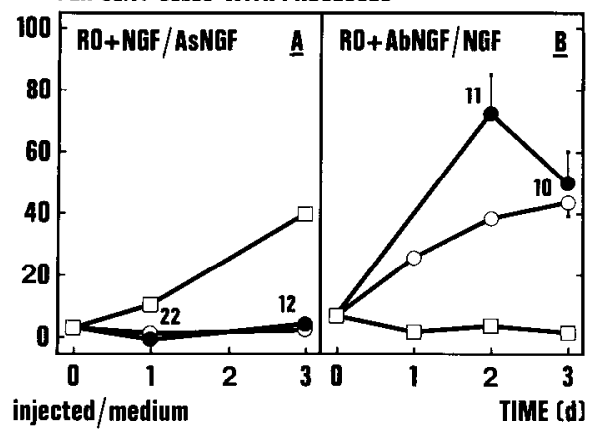

Figure 3. Neurite outgrowth from naive cells: nuclear injections. microinjected cells; $\bigcirc$, control, non-injected cells from the same plate as microinjected cells; $\square$, cells from non-injected sister cultures given the converse external NGF treatment to injected cells. In $A$, injected and non-injected cells received extracellular AsNGF, whereas sister cultures received extracellular NGF; in $B$, injected and non-injected cells received extracellular NGF, whereas sister cultures wcre in NGF-free medium. The compositions of the injection solutions and of media, indicated in each panel as injected solution/medium, are given under "Materials and Methods." Other details are given in the legend to Figure 2. into the nucleus did not elicit process outgrowth, nor was outgrowth inhibited by injected antibodies. It does not appear, therefore, that material injected into the cytoplasm is limited in its action by the permeability of the nuclear membrane.

Process regeneration by injected "primed" cells. For PC12 cells, NGF-dependent neurite outgrowth from naive and NGF-pretreated cells have been shown to differ both in their rates and in their requirements for transcription (Burstein and Greene, 1978). That is, naive PC12 cells generate neurites over days by a transcriptiondependent mechanism, whereas cells that have been "primed" by pre-exposure to NGF regenerate neurites within $24 \mathrm{hr}$ independently of transcription. The content of $\left[\mathrm{I}^{125}\right] \mathrm{NGF}$ (Yankner and Shooter, 1979) and the disposition of such material (Bernd and Greene, 1983) also vary with time of NGF treatment of the PC12 cell. Since the rate of process growth for NGF-dependent regeneration in PC12 cells is high $\left(250 \mu \mathrm{m}\right.$ day $\left.^{-1}\right)$, this system represents a sensitive and rapid assay for neurite growth. A number of microinjection experiments were carried out on "primed" PC12 cells. The cultures were allowed to develop neurites in the presence of $\mathrm{NGF}$ for 8 to 13 days and then were detached from the substratum, washed, and replated under a variety of conditions. The process of subculturing involved severance of cell bodies from neurites. The replated "primed" cells were allowed to reattach to the substrate, and microinjections were then carried out as for the experiments on naive PC12 cells. The cells were scored after 1 day of incubation using the standard criteria, except that the minimum value for process length was $20 \mu \mathrm{m}$ rather than $10 \mu \mathrm{m}$. Results of cytoplasmic injections of "primed" cells are presented in Figure 4 . About $80 \%$ of the cells regenerated processes of more than $20 \mu \mathrm{m}$ after 1 day of treatment with NGF. As for naive PC12 cells, injection of $\mathrm{RO}$ alone did not influence NGF-dependent process outgrowth. Microinjected NGF did not induce process regeneration in the absence of extracellular NGF, nor did it cause any significant enhancement of events elicited by the extracellular NGF. Anti-NGF IgG injected into the cytoplasm did not inhibit the action of NGF present in the medium. Not only did injected cells match non-injected controls for elongation of processes, they appeared morphologically indistinguishable.

Finally, nuclear injections were performed for regeneration of processes. The results are shown in Figure 5. NGF microinjected into the nucleus failed to induce or accelerate regeneration. Thus, as for naive $\mathrm{PC} 12$ cells, microinjected proteins were ineffective in altering NGFdependent process formation.

\section{Discussion}

NGF, which had been introduced into PC12 cells by pressure microinjection into the cytoplasm, was not able to induce neurite growth in either naive cells or those pretreated with NGF, nor was it able to enhance responses to NGF added to the culture medium. This occurred in the absence of any inhibition of NGF-induced neurite growth by the process of injection itself. In parallel experiments, cytoplasmic microinjection of antiNGF antibodies did not cause neurite outgrowth to be inhibited for cells which either had or had not received 
PER CENT CELLS WITH PROCESSES

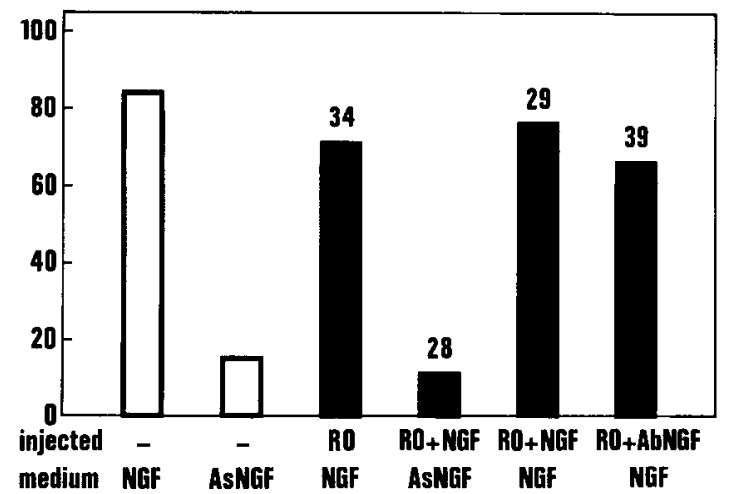

Figure 4. Neurite outgrowth from primed cells: cytoplasmic injections. The cells were "primed" by maintenance in medium containing $50 \mathrm{ng} \mathrm{ml}^{-1} \mathrm{NGF}$ for 8 days. They were then washed free of NGF and subcultured onto four plates; then some cells were microinjected as described in the text. Scoring took place $24 \mathrm{hr}$ after injection; cells were scored positive for outgrowth if they had at least one process of $20 \mu \mathrm{m}$ or more in length. Numbers above the solid bars are total numbers of injected cells scored. Control counts of non-injected cells (open bars) are based on 100 cells. For the first plate, cells were injected with $\mathrm{RO}$ and the culture medium contained $50 \mathrm{ng} \mathrm{ml^{-1 }} \mathrm{NGF}$; this plate was also used to score neurite outgrowth from noninjected cells. For the second plate, cells were injected with $\mathrm{RO}$ $+\mathrm{NGF}$ and the medium contained AsNGF; residual neurite outgrowth from non-injected cells was also scored from this plate. For the third plate, cells were injected with $\mathrm{RO}+\mathrm{NGF}$ and the medium contained $50 \mathrm{ng} \mathrm{ml}^{-1} \mathrm{NGF}$. For the fourth plate, cells were injected with $\mathrm{RO}+\mathrm{AbNGF}$ and the medium contained $50 \mathrm{ng} \mathrm{ml}^{-1} \mathrm{NGF}$. For these third and fourth plates, neurite outgrowth from non-injected cells was nearly equal to that for the first plate. Compositions of injected solutions and media are given under "Materials and Methods."

PER CENT CELLS WITH PROCESSES

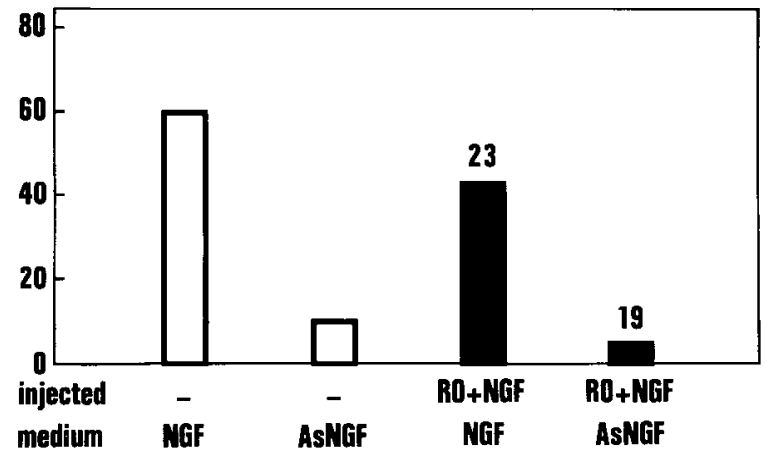

Figure 5. Neurite outgrowth from primed cells: nuclear injections. The cells were "primed" by maintenance in medium containing $50 \mathrm{ng} \mathrm{ml}^{-1} \mathrm{NGF}$ for 8 days, washed free of NGF, and subcultured onto two plates; then some cells were microinjected as described under "Materials and Methods." Composition of injection solutions and media are also given under "Materials and Methods." For the first plate, cells were injected with RO $+\mathrm{NGF}$ and the medium contained $50 \mathrm{ng} \mathrm{ml}^{-1} \mathrm{NGF}$; this plate was also used for scoring neurite outgrowth from non-injected cells. For the second plate, cells were injected with RO + NGF and the medium contained AsNGF; this plate was also used for scoring residual neurite growth from non-injected cells. Other details are given in the legend to Figure 4. prior exposure to NGF. These data are in agreement with those from fusion microinjection experiments of Ileumann et al. (1981) and with Huttner and O'Lague's (1981) pressure microinjection experiments with PC12 heterokaryons; the results extend the situations covered to neurite regeneration by the $\mathrm{PC} 12$ clone. In addition, from the present experiments, it was shown that material which had direct access to the nucleus as a result of nuclear injeclion had no more effect on neurite growth than that introduced by injection into the cytoplasm.

These experiments are strong evidence against intracellular action of NGF at the nuclear or cytoplasmic level as being sufficient for neurite outgrowth. In particular they discount modes of action involving direct binding of NGF to cytoskeletal tubulin and actin (Levi et al., 1975; Calissano et al., 1978; Nasi et al., 1982) and any mechanisms involving freely accessible receptor or acceptor sites. The intranuclear injections of anti-NGF IgG also counter pathways involving simple exposure of NGF within the nucleoplasm. If the results of Andres et al. (1977), Yankner and Shooter (1979), and Bernd and Greene (1983) are taken as indicating physiologically significant levels of NGF in nuclear structures, this material must be present in a form that is latent or else no longer recognizable by anti-NGF antibodies.

This type of experiment is limited by the possibility of rapid degradation of injected proteins. Native proteins injected into cells have been found to turn over with a half-time of about 1 day (Stacey and Allfrey, 1977; Zavortink et al., 1979) and there is variation from protein to protein. For this reason, by comparison with the measured value for NGF uptake $\left(11 \mathrm{fmol}\left(10^{6} \text { cells }\right)^{-1}\right.$ over $24 \mathrm{hr}$ (Yankner and Shooter, 1979)), large quantities of NGF and of anti-NGF IgG were injected (64 and 55 times, respectively). The fluorescence of $\mathrm{RO}$ used to mark injected cells decreased by about a factor of 3 over 3 days $\left(t_{1 / 2}, \sim 2\right.$ days on the assumption of exponential decay). If the same rate of decay of protein pertained to injected NGF or anti-NGF, there would still be a comparatively large quantity of injected protein in the cell after 3 days of incubation (21 and 18 times the Yankner and Shooter (1979) quantity for NGF and anti-NGF, respectively). Also, the neurite regeneration experiments carried out over 1 day represent a much shorter period over which degradation of injected material might occur. Finally, it is relevant to note that the flattening responses which PC12 cells undergo within the first hour after addition of NGF (P. J. Seeley, L. Blum, and L. A. Greene, unpublished observations) did not occur with microinjected NGF, either within $24 \mathrm{hr}$ in these experiments or over shorter time periods in the experiments of Huttner and O'Lague (1981). It is therefore unlikely that the lack of effects of injected proteins on neurite outgrowth is caused by limitations in their supply.

Given that arguments about adequate supply of injected NGF and anti-NGF IgG have been countered, the failure of microinjected NGF and anti-NGF to affect neurite outgrowth raises two possibilities. As Heumann et al. (1981) have proposed, binding of NGF to cell surface receptors may be entirely sufficient for elicitation-by a second messenger system-of intracellular events involved in neurite outgrowth. Alternatively, intracellular action of NGF may be necessary for neurite outgrowth, 
but factor acting from within the cell may not be directly accessible to the cytoplasm or nucleoplasm. This second possibility seems plausible in view of the likely mode of internalization of NGF-receptor complexes taken into the cell from the external surface (Levi et al., 1980). Such complexes may represent the active form of intracellular NGF and, because of their likely intracisternal location, may be inaccessible to microinjected proteins. They may also be processed in transit so as to be no longer recognizable by anti-NGF antibodies. Yankner and Shooter (1982) have proposed such a model for translocation of extracellular NGF to the nucleus and have provided some evidence in its support.

In summary, with respect to neurite outgrowth, these experiments rule out any simple intracellular role for NGF which involves its free accessibility in the cytoplasm or nucleoplasm, but they allow alternative mechanisms involving internalization via conventional endocytotic pathways.

\section{References}

Andres, R. Y., I. Jeng, and R. A. Bradshaw (1977) Nerve growth factor receptors: Identification of distinct classes in plasma membranes and nuclei of embryonic dorsal root neurons. Proc. Natl. Acad. Sci. U. S. A. 74: 2785-2789.

Beckerle, M. C., and K. R. Porter (1982) Inhibitors of dynein activity block intracellular transport in erythrophores. Nature 295: 701-703.

Bernd, P., and L. A. Greene (1983) Electron microscopic radioautographic localization of iodinated nerve growth factor bound to and internalized by PC12 cells. J. Neurosci. 3: 631643.

Bornstein, M. B. (1958) Reconstituted rat-tail collagen used as substrate for tissue cultures on coverslips in Maximow slides and roller tubes. Lab. Invest. 7: 134-137.

Burstein, D. E., and L. A. Greene (1978) Evidence for both RNA synthesis-dependent and -independent pathways in stimulation of neurite outgrowth by nerve growth factor. Proc, Natl. Acad. Sci. U. S. A. 75: 6059-6063.

Calissano, P., G. Monaco, L. Castellani, D. Mercanti, and A. Levi (1978) Nerve growth factor potentiates actomyosin adenosinetriphosphatase. Proc. Natl. Acad. Sci. U. S. A. 75: 2210-2214.

Carbonetto, S., and R. W. Stach (1982) Localization of nerve growth factor bound to neurons growing nerve fibers in culture. Dev. Brain Res. 3: 463-473.

Claude, P., E. Hawrot, D. A. Dunis, and R. B. Campenot (1982) Binding, internalization, and retrograde transport of ${ }^{125} \mathrm{I}$ nerve growth factor in cultured sympathetic neurons. J. Neurosci. 2: 431-442.

Greene, L. A., and E. M. Shooter (1980) The nerve growth factor: Biochemistry, synthesis, and mechanism of action. Annu. Rev. Neurosci. 3: 353-402.

Greene, L. A., and A. S. Tischler (1976) Establishment of a noradrenergic clonal line of rat adrenal pheochromocytoma cells which respond to nerve growth factor. Proc. Natl. Acad. Sci. U. S. A. 73: 1414-1418.

Greene, L. A., and A. S. Tischler (1982) PC12 pheochromocytoma cultures in neurobiological research. Adv. Cell. Neurobiol. 3: 373-414.
Gunning, P. W., G. E. Landreth, P. Layer, M. Ignatius, and E. M. Shooter (1981) Nerve growth factor-induced differentiation of PC12 cells: Evaluation of changes in RNA and DNA metabolism. J. Neurosci. 1: 368-379.

Hendry, I. A., K. Stockel, H. Thoenen, and L. L. Iversen (1974) The retrograde axonal transport of nerve growth factor. Brain Res. 68: 102-121.

Heumann, R., M. Schwab, and H. Thoenen (1981) A second messenger required for nerve growth factor biological activity. Nature 292: 838-840.

Hogue-Angeletti, R., A. Stieber, and N. K. Gonatas (1982) Endocytosis of nerve growth factor by PC12 cells studied by quantitative ultrastructural autoradiography. Brain Res. 241: $145-156$.

Huttner, S., and P. O'Lague (1981) Absence of morphological responses to intracellular injection of nerve growth factor into cells of the neuron-like clone PC-12. Soc. Neurnsci. Abstr. 7: 551.

Kulka, R. G., and A. Loyter (1979) The use of fusion methods for the microinjection of animal cells. Curr. Top. Membr. Transp. 12: 365-430.

Levi, A., M. Cimino, D. Mercanti, J. S. Chen, and P. Calissano (1975) Interaction of nerve growth factor with tubulin. Studies on binding and induced polymerization. Biochim. Biophys. Acta 399: 50-60.

Levi, A., Y. Shechter, E. J. Neufeld, and J. Schlessinger (1980) Mobility, clustering, and transport of nerve growth factor in embryonal sensory cells and in a sympathetic neuronal cell line. Proc. Natl. Acad. Sci. U. S. A. 77: 3469-3473.

Mobley, W. C., A. Schenker, and E. M. Shooter (1976) Characterization and isolation of proteolytically modified nerve growth factor. Biochemistry 15: 5543-5552.

Nasi, S., D. Cirillo, L. Naldini, P. C. Marchisio, and P. Calissano (1982) Microtubules and microfilaments in fixed and permeabilized cells are selectively decorated by nerve growth factor. Proc. Natl. Acad. Sci. U. S. A. 79: 820-824.

Norr, S. C., and S. Varon (1975) Dynamic, temperature-sensitive association of ${ }^{125}$ I-nerve growth factor in vitro with ganglionic and nonganglionic cells from embryonic chick. Neurobiology 5: 101-118.

Rohrer, H., T. Schäfer, S. Korsching, and H. Thoenen (1982) Internalization of nerve growth factor by pheochromocytoma PC12 cells: Absence of transfer to the nucleus. J. Neurosci. 2: 687-697.

Schwab, M., and H. Thoenen (1977) Selective trans-synaptic migration of tetanus toxin after retrograde axonal transport in peripheral sympathetic nerves: A comparison with nerve growth factor. Brain Res. 122: 459-474.

Stacey, D. W., and V. G. Allfrey (1977) Evidence for the autophagy of microinjected proteins in HeI a cells. J. Cell Biol. 75: 807-817.

Yankner, B. A., and E. M. Shooter (1979) Nerve growth factor in the nucleus: Interaction with receptors on the nuclear membrane. Proc. Natl. Acad. Sci. U. S. A. 76: 1269-1273.

Yankner, B. A., and E. M. Shooter (1982) The biology and mechanism of action of nerve growth factor. Annu. Rev. Biochem. 51: 845-868.

Zanini, A., P. Angeletti, and R. Levi-Montalcini (1968) Immunochemical properties of the nerve growth factor. Proc. Natl. Acad. Sci. U. S. A. 61: 835-842.

Zavortink, M., T. Thacher, and M. Rechsteiner (1979) Degradation of proteins microinjected into cultured mammalian cells. J. Cell. Physiol. 100: 175-186. 